\title{
Original Research \\ Effects of Long-Term Organic and Mineral Fertilizer Applications on Soil Nitrogen Content
}

\author{
Zbigniew Mazur*, Teofil Mazur \\ Chair of Environmental Chemistry, University of Warmia and Mazury in Olsztyn, \\ pl. Lodzki 4, 10-727 Olsztyn, Poland
}

Received: July 17, 2014

Accepted: April 20, 2015

\begin{abstract}
Our work discusses the influence of the annual application of manure, slurry, and NPK fertilizer for a period of many years on the total, hydrolyzable, and mineral nitrogen content in the arable layer of lessive and brown soils. Annual fertilization resulted in an average increase in total nitrogen content of $27.3 \%$ in lessive soil and $48.4 \%$ in brown soil, and in the case of hydrolyzable nitrogen, increases of $25.6 \%$ and $51.3 \%$, respectively, when compared to the control objects. In total nitrogen content the share of hydrolyzable nitrogen was found to be $59.7 \%$ in lessive soil and $63.3 \%$ in brown soil. The content of mineral nitrogen in fertilized objects showed an increase in the range of 5.5-20.6 mg. kg ${ }^{-1}$ in lessive soil and $5.0-13.0 \mathrm{mg} \cdot \mathrm{kg}^{-1}$ in brown soil. For lessive soil, the percentage share of $\mathrm{N}^{-\mathrm{NH}_{4}}$ and $\mathrm{N} \mathrm{NO}_{3}$ in mineral nitrogen was, on average, $55 \%$ and $45 \%$, whereas in brown soil these figures were found to be $75 \%$ and $25 \%$, respectively. A significant positive correlation was confirmed between the analyzed forms of nitrogen only in the case of brown soil.
\end{abstract}

Keywords: organic fertilization, mineral fertilization, nitrogen forms, soil

\section{Introduction}

Nitrogen in one of the most important plant nutrients in terms of improving crop yield, but at the same time poses a threat to the natural environment. This is largely due to the lability of this nutrient in a soil environment and the fact that it is not utilized effectively by crops $[1,2]$. As a result, scientific research aimed at limiting its losses and maximizing its uptake by plants is being conducted [3, 4]. Nitrogen losses from mineral fertilizers occur when they are introduced into the soil, and in the case of natural and organic ones (over a period of 2-3 years), during their mineralization [5]. It has been empirically proven that nitrogen is utilized by $40-50 \%$, and in the case of favorable agrotechnical conditions, reaches levels of $60 \%$ [6, 7]. Its remaining amount undergoes losses mostly through evaporation into the atmosphere in the form of $\mathrm{NH}_{3}, \mathrm{NO}_{2}$, and $\mathrm{N}_{2}$ (products

*e-mail: zbigniew.mazur@uwm.edu.pl of denitrification), as well as the leaching of its mineral forms - mainly $\mathrm{NO}_{3}$ - to deeper layers of the soil profile and into groundwater [8-12]. An insignificant portion of nitrogen remains in the soil in the form of compounds that do not undergo mineralization easily. This is so-called reserve nitrogen, partially remobilized in processes of a severe deficit of absorbable forms. These processes occur simultaneously to the decomposition of humus compounds in soil, which has been demonstrated by Cameron et al. [7] as well as Kaur and Singh [13].

The aim of the work was to compare total, hydrolysable, and mineral nitrogen contents in the soils of two multi-year fertilization experiments.

\section{Materials and Methods}

Soil samples were collected for analysis from two parallel field experiments carried out in a randomized com- 
Table 1. Doses of fertilizer components applied in the experiments $\left(\mathrm{kg} \cdot \mathrm{ha}^{-1}\right)$.

\begin{tabular}{|l|c|c|c|c|c|c|c|c|}
\hline \multirow{3}{*}{ Fertilization } & \multicolumn{4}{|c|}{ Experiment I with cow slurry } & \multicolumn{4}{c|}{ Experiment II with swine slurry } \\
\cline { 2 - 10 } & \multicolumn{4}{|c|}{ Average for years 1972-2006 } & \multicolumn{4}{c|}{ Average for years 1973-2007 } \\
\cline { 2 - 10 } & $\mathrm{N}$ & $\mathrm{P}$ & $\mathrm{K}$ & $\mathrm{Mg}$ & $\mathrm{N}$ & $\mathrm{P}$ & $\mathrm{K}$ & $\mathrm{Mg}$ \\
\hline Slurry dI & 111 & 49 & 126 & 20 & 129 & 53 & 80 & 21 \\
\hline Slurry dI + PK & 111 & 67 & 181 & 20 & 129 & 74 & 141 & 21 \\
\hline Slurry dII & 205 & 88 & 227 & 37 & 384 & 182 & 228 & 50 \\
\hline Slurry dII + PK & 205 & 102 & 282 & 37 & 384 & 203 & 289 & 50 \\
\hline Manure & 111 & 37 & 92 & 21 & 129 & 42 & 102 & 19 \\
\hline Manure +PK & 111 & 55 & 147 & 21 & 129 & 63 & 163 & 19 \\
\hline NPK & 111 & 38 & 110 & - & 129 & 42 & 122 & - \\
\hline
\end{tabular}

plete block design in six replications. The surface area of a plot for harvest was $45 \mathrm{~m}^{2}$. Organic (manure, slurry in two doses) and mineral fertilizers were used. In addition to blocks subjected only to organic fertilization, ones where this form of fertilization was supplemented with mineral fertilization (PK) was also set up. Phosphorus and potassium fertilizers were applied in amounts equivalent to half the content of these components applied in the case of solely mineral fertilization.

Experiment I was set up in 1972 in Balcyny (53'35'45" $\mathrm{N}, 19^{\circ} 51^{\prime} 06^{\prime \prime} \mathrm{E}$ ) on lessive soil of a good rye complex of soil valuation class IVa, with the application of cow manure and slurry. The arable layer of the soil was characterized by sandy clay with $5-7 \%$ silt and clay fractions. The average annual rainfall is $642 \mathrm{~mm}$, the average annual temperature is $7.4^{\circ} \mathrm{C}$. Experiment II was set up in 1973 in Tomaszkowo $\left(53^{\circ} 35^{\prime} 45^{\prime \prime} \mathrm{N}, 19^{\circ} 51^{\prime} 06^{\prime \prime} \mathrm{E}\right)$ on brown soil of a rye complex of soil valuation class $\mathrm{IVb}$, with the application of pig manure and slurry. The arable layer of the soil was characterized by slightly loamy sand with $2-2.5 \%$ silt and clay fractions. The average annual rainfall is $647 \mathrm{~mm}$, the average annual temperature is $7.5^{\circ} \mathrm{C}$.
Slurry applied in dose I (dI), manure, and mineral fertilization were applied in doses balanced with nitrogen. The value of dose II (dII) of slurry was determined in such a way so that the amount of organic carbon introduced with it would be equal to that of the manure dose. The average yearly doses of fertilizer components are presented in Table 1. The slurry and manure doses were calculated each year directly prior to being introduced into the soils on the basis of dry matter, organic carbon, and nitrogen content.

The same species of plants were cultivated in the experiments in the following crop rotation: potato, spring barley+red clover and grass companion crop (in two rotations on lessive soil and one rotation on brown soil), winter rapeseed, winter wheat+winter rye aftercrop, corn for silage, spring barley, and winter or spring wheat.

Soil samples for chemical analyses were collected in 2006 (experiment I) and in 2007 (experiment II) from the 0-25 cm layer of soil following the harvest of crops. In each plot, 10 soil sub-samples were taken and prepared for analysis by drying at room temperature and sifting them through a $1 \mathrm{~mm}$ nylon screen. Total nitrogen content was determined in the dry mass of soil using the Kjeidahl

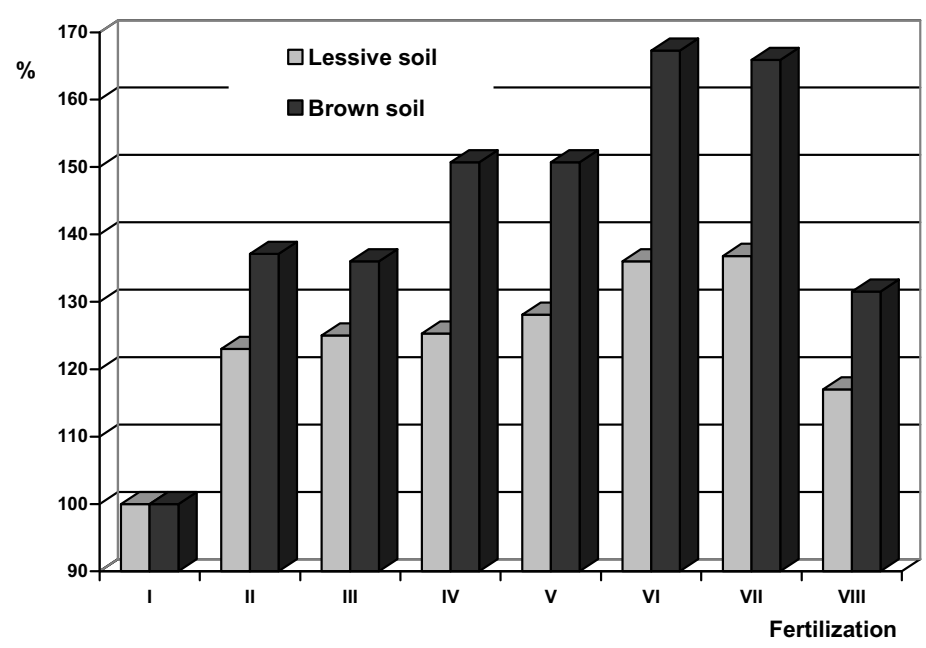

Fig. 1. Influence of multi-year fertilization on relative increases in total nitrogen content. 
Table 2. Total nitrogen and hydrolyzable nitrogen content in soils of multi-year fertilization experiments.

\begin{tabular}{|l|c|c|c|c|c|c|}
\hline \multirow{2}{*}{ Fertilization } & \multicolumn{3}{|c|}{ Lessive soil } & \multicolumn{2}{c|}{ Brown soil } \\
\cline { 2 - 7 } & $\begin{array}{c}\text { Total N } \\
\mathrm{g} \cdot \mathrm{kg}^{-1}\end{array}$ & $\begin{array}{c}\mathrm{N}_{\text {hyd }} \\
\mathrm{g} \cdot \mathrm{kg}^{-1}\end{array}$ & $\begin{array}{c}\text { Share } \mathrm{N}_{\text {hyd }} \\
\%\end{array}$ & $\begin{array}{c}\text { Total N } \\
\mathrm{g} \cdot \mathrm{kg}^{-1}\end{array}$ & $\begin{array}{c}\mathrm{N}_{\text {hyd }} \\
\mathrm{g} \cdot \mathrm{kg}^{-1}\end{array}$ & $\begin{array}{c}\text { Share } \mathrm{N}_{\text {hyd }} \\
\%\end{array}$ \\
\hline I No fertilization & 0.846 & 0.509 & 60.2 & 0.428 & 0.266 & 62.1 \\
\hline II Slurry dI & 1.041 & 0.624 & 59.9 & 0.587 & 0.354 & 58.1 \\
\hline III Slurry dI+PK & 1.058 & 0.680 & 61.4 & 0.582 & 0.341 & 60.8 \\
\hline IV Slurry dII & 1.060 & 0.676 & 63.8 & 0.645 & 0.382 & 59.2 \\
\hline V Slurry dII+PK & 1.084 & 0.673 & 62.1 & 0.645 & 0.444 & 68.8 \\
\hline VI Manure & 1.151 & 0.619 & 58.1 & 0.716 & 0.465 & 64.9 \\
\hline VII Manure+PK & 1.157 & 0.657 & 56.8 & 0.710 & 0.491 & 69.2 \\
\hline VIII NPK & 0.390 & 0.547 & 55.2 & 0.563 & 0.348 & 61.8 \\
\hline Average & $1.048^{\mathrm{a}}$ & $0.638^{\mathrm{b}}$ & 59.7 & $0.610^{\mathrm{a}}$ & $0.386^{\mathrm{b}}$ & 63.3 \\
\hline LSD $_{0.05}$ & 0.030 & 0.120 & - & 0.021 & 0.089 & - \\
\hline
\end{tabular}

a-a, b-b - insignificant differences at $\mathrm{p}<0.05$

method, with hydrolyzable nitrogen determined in $6 \mathrm{M} \mathrm{HCl}$ $\left(24 \mathrm{~h}\right.$ at $\left.105^{\circ} \mathrm{C}\right)$ [14]. Ammonia nitrogen and nitrate nitrogen (V), on the other hand, were determined in fresh soil samples using the Convey method and colorimetrically with phenolsulfonic acid, respectively. The results of each experiment were subjected to statistical analysis using Tukey's analysis of variance. The experiments were compared with the t-test for independent variables, assessing differences between the average results. The Statistica 10 program was used.

\section{Results and Discussion}

The total nitrogen $\left(\mathrm{N}_{\text {tot }}\right)$ and hydrolyzable nitrogen $\left(\mathrm{N}_{\text {hyd }}\right)$ content in soils of multi-year fertilization experiments are presented numerically in Table 2 . The average
$\mathrm{N}_{\text {tot }}$ and $\mathrm{N}_{\text {hyd }}$ contents were, respectively, 1.72 times and 1.65 times higher in lessive soil than in brown soil. The applied fertilization caused an average $\mathrm{N}_{\text {tot }}$ increase of $0.231 \mathrm{~g} \cdot \mathrm{kg}^{-1}$ in lessive soil and $0.207 \mathrm{~g} \cdot \mathrm{kg}^{-1}$ in brown soil when compared to the control group. A higher relative increase in $\mathrm{N}_{\text {tot }}$ content was confirmed in the case of brown over lessive soil (Fig. 1). In the case of the first, the average relative increase in $\mathrm{N}_{\text {tot }}$ was $48.4 \%$, with a $27.3 \%$ increase reported in lessive soil as compared to the control. These differences in soils with organic fertilizers are much higher than those observed in soils to which NPK fertilization was applied. A more positive influence of organic fertilizers over their mineral counterparts on storing nitrogen in soils was reported by Gao et al. [15], whereas in 2010, Wang et al. [16] and Li et al. [17] proved that the long-term application of manure leads to a significant increase in the nitrogen content of soils.

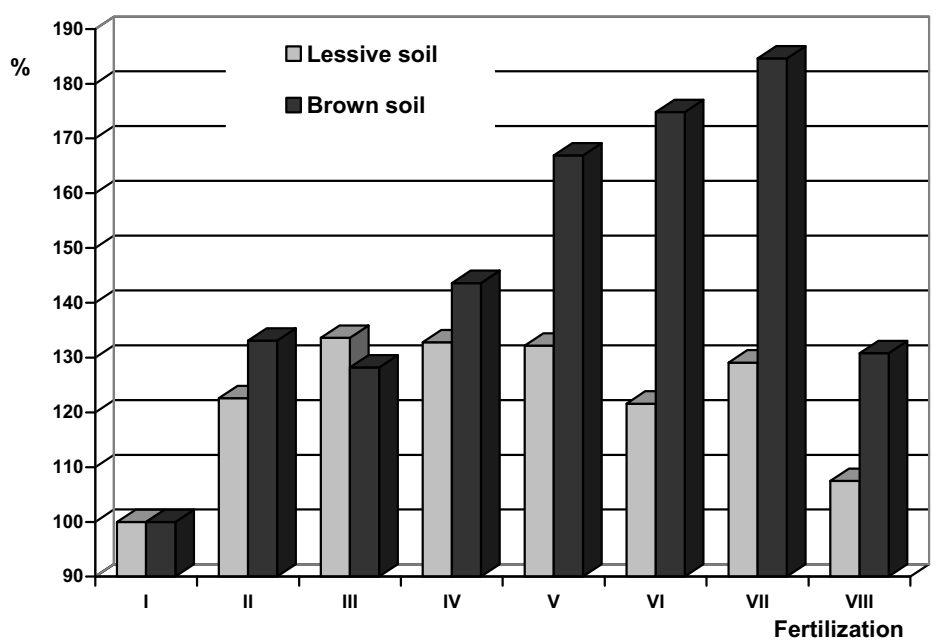

Fig. 2. Influence of multi-year fertilization on relative increases in hydrolyzable nitrogen content. 
Table 3. Content of mineral forms of nitrogen in lessive and brown soil.

\begin{tabular}{|c|c|c|c|c|c|c|}
\hline \multirow{3}{*}{ Fertilization } & \multicolumn{3}{|c|}{ Lessive soil } & \multicolumn{3}{|c|}{ Brown soil } \\
\hline & \multicolumn{6}{|c|}{$\mathrm{mg} \cdot \mathrm{kg}^{-1}$} \\
\hline & $\mathrm{N}-\mathrm{NH}_{4}$ & $\mathrm{~N}-\mathrm{NO}_{3}$ & Sum & $\mathrm{N}-\mathrm{NH}_{4}$ & $\mathrm{~N}-\mathrm{NO}_{3}$ & Sum \\
\hline I No fertilization & 8.25 & 4.65 & 12.90 & 7.50 & 2.65 & 10.15 \\
\hline II Slurry dI & 11.00 & 7.40 & 18.40 & 12.65 & 3.75 & 16.40 \\
\hline III Slurry dI+PK & 10.70 & 9.55 & 20.25 & 13.40 & 4.25 & 17.65 \\
\hline IV Slurry dII & 11.55 & 11.40 & 22.95 & 14.10 & 4.90 & 19.00 \\
\hline V Slurry dII+PK & 12.20 & 11.15 & 23.35 & 15.30 & 5.35 & 20.65 \\
\hline VI Manure & 17.25 & 14.45 & 31.70 & 17.40 & 5.60 & 23.00 \\
\hline VII Manure+PK & 17.65 & 15.85 & 33,5 & 17.20 & 5.95 & 23.15 \\
\hline VIII NPK & 11.75 & 9.45 & 21.20 & 11.25 & 3.90 & 15.15 \\
\hline Average & $12.54^{\mathrm{a}}$ & $10.24^{\mathrm{b}}$ & 22.78 & $13.60^{\mathrm{a}}$ & $4.54^{\mathrm{b}}$ & 18.14 \\
\hline $\mathrm{LSD}_{0.05}$ & 1.32 & 1.50 & - & 1.03 & 0.91 & - \\
\hline
\end{tabular}

a-a, b-b - insignificant differences at $\mathrm{p}<0.05$

Determining hydrolyzable nitrogen in soils allows us to assess nitrogen compounds susceptible to mineralization. Based on the numerical data presented in Table 3, the share of $\mathrm{N}_{\text {hyd }}$ in $\mathrm{N}_{\text {tot }}$ was more strongly influenced by fertilization than by soil type. The average difference between the soils was found to be merely $3.6 \%$, whereas differences between the $\mathrm{N}_{\text {tot }}$ content in soils subjected to the two types of fertilization were $8.6 \%$ and $10.7 \%$ for lessive soil and brown soil, respectively. Slurry dII led to the most significant increase of $\mathrm{N}_{\text {hyd }}$ in lessive soil, whereas brown soil was most affected by manure and slurry dII. Additional PK fertilization had a positive impact on the share of $\mathrm{N}_{\text {hyd }}$ in $\mathrm{N}_{\text {tot }}$ only when applied to brown soil.

The relative increase in the content of $\mathrm{N}_{\text {hyd }}$ as a result of fertilization is depicted by data in Fig. 2. In lessive soil, this increase was found to be $25.6 \%$ with oscillations ranging from $7.5 \%$ in land fertilized with NPK to $32.8 \%$ in land fertilized with slurry dII. In brown soil, the average increase of $\mathrm{N}_{\text {hyd }}$ was $51.7 \%$, oscillating from $28.2 \%$ for slurry dI fertilization to $84.6 \%$ when manure+PK was applied. The varied influence of long-term organic, organic-mineral, and mineral fertilization on the content of hydrolyzable nitrogen in soils was revealed by Kaur and Singh [13].

The influence of multi-year fertilization on the content of mineral nitrogen in soils is demonstrated by numerical data in Table 3. The average $\mathrm{N}_{\min }$ content in lessive soil was 1.24 times higher than in the case of brown soil. From among the blocks in which fertilizers balanced with nitrogen were applied, the highest content of $\mathrm{N}_{\text {min }}$ was noted in those fertilized with manure. When compared to manure (accepted as 100\%), the effect of slurry dI was $58.0 \%$ in lessive soil and $71.3 \%$ in brown soil, whereas in NPK objects these values were $66.9 \%$ and $65.9 \%$, respectively. Slurry applied in dII was also not as effective as manure, as its effect was merely $72.4 \%$ and $82.6 \%$, depending on soil type. Additional PK fertilization helped increase $\mathrm{N}_{\text {min }}$ content in lessive soil by $5.8 \%$, and in brown soil by $8.1 \%$, but only in the case of land fertilized with slurry. The fact that $\mathrm{N}_{\min }$ content increases in soils fertilized with manure is supported by the increase in the content of humus compounds, as reported by Tomov and Artinova [18], Stępień and Adamiak [19], and Kristaponyte [20].

The percentage share of $\mathrm{N}-\mathrm{NH}_{4}$ and $\mathrm{N}_{-} \mathrm{NO}_{3}$ in mineral nitrogen is important in the ecological sense [21]. The agronomical properties of soil and type of applied fertilizer influenced the content of these two types of nitrogen. In lessive soil, their percentage share was 55\% and $45 \%$, with $75 \%$ and $25 \%$ in the case of brown soil. The small share of $\mathrm{N}-\mathrm{NO}_{3}$ in mineral nitrogen in brown soil was most likely caused by the greater leaching of nitrates (V) from the soil as a result of precipitation. Mention of this was made by Erhart et al. [22], Richards et al. [23], and Haberle and Káš [24]. The observed situation also depends on the enzymatic properties of soil, as indicated by Piotrowska [25]. According to Anggria et al. [26], the share of $\mathrm{N}-\mathrm{NH}_{4}$ and $\mathrm{N}-\mathrm{NO}_{3}$ in $\mathrm{N}_{\text {min }}$ depends on the type of organic matter, its application to soil, and microbiological activity, as well as the water and air content of soil. When analyzing agricultural soils in eastern Poland in 2004-06, Dresler et al. [27] stated that $\mathrm{N}^{-\mathrm{NO}_{3}}$ content in soils depends on the dosage of nitrogen and type of fertilizer (organic, mineral), the species of cultivated crop, atmospheric conditions, and the physico-chemical properties of the soil. The determined forms of nitrogen were used to calculate Pearson's simple correlation coefficients (Table 4). In lessive soil, significant correlations between $\mathrm{N}_{\text {tot }}$ and $\mathrm{N}-\mathrm{NH}_{4}$, and $\mathrm{N}_{\text {tot }}$ and $\mathrm{N}-\mathrm{NO}_{3}$ were not observed. In brown soil, all of the analyzed forms of nitrogen were significantly correlated with each other. 
Table 4. Linear correlation coefficients between nitrogen form contents in lessive and brown soils.

\begin{tabular}{|c|c|c|c|}
\hline \multicolumn{5}{|c|}{ Lessive soil } \\
\hline Nitrogen & Total N & $\mathrm{N}_{\text {hyd }}$ & N-NH \\
\hline $\mathrm{N}_{\text {hyd }}$ & $0.70^{*}$ & - & - \\
\hline $\mathrm{N}_{-} \mathrm{NH}_{4}$ & $0.41^{*}$ & $0.36^{*}$ & - \\
\hline $\mathrm{N}^{*} \mathrm{NO}_{3}$ & $0.45^{*}$ & $0.58^{*}$ & $0.94^{* *}$ \\
\hline \multicolumn{5}{|c|}{ Brown soil } \\
\hline $\mathrm{N}_{\text {hyd }}$ & $0.95^{* *}$ & - & - \\
\hline $\mathrm{N}^{*} \mathrm{NH}_{4}$ & $0.99^{* *}$ & $0.95^{* *}$ & - \\
\hline $\mathrm{N}^{*} \mathrm{NO}_{3}$ & $0.97^{* *}$ & $0.97^{* *}$ & $0.97^{* *}$ \\
\hline
\end{tabular}

significant at: $* \mathrm{p}<0.05, * * \mathrm{p}<0.001$

\section{Conclusions}

Experiments in which manure, slurry, and NPK fertilizer were applied for a period of 34 years revealed that the increase in the content of the analyzed forms of nitrogen was dependant on the kind of soil and type of fertilizer applied. The content of $\mathrm{N}_{\text {tot }}$ in lessive soil, which was characterized by higher contents, exhibited a lower relative increase than in the case of brown soil containing less $\mathrm{N}_{\text {tot }}$. Among the doses of fertilizers balanced with nitrogen, manure was found to be most effective in increasing the contents of the analyzed element in soil, followed by slurry and - lastly - mineral fertilization. The effects of applying increased doses of slurry were also not as significant as when manure was applied.

The content of hydrolyzable nitrogen also differed depending on soil type and the applied fertilizers. Despite this, the percentage share of $\mathrm{N}_{\text {hyd }}$ in $\mathrm{N}_{\text {tot }}$ was found to be at similar levels. When compared to the control blocks, fertilization had a significant effect on the average percentage share of hydrolyzable nitrogen in total nitrogen. The content of mineral nitrogen in lessive soil was on average 1.26 times higher than in brown soil. The applied fertilization led to a higher relative increase in $\mathrm{N}_{\min }$ in brown soil than in its lessive counterpart, with the difference amounting to $20.3 \%$. Marked differences were confirmed in the contents of $\mathrm{N}-\mathrm{NH}_{4}$ and $\mathrm{N}-\mathrm{NO}_{3}$. Nitrates (V) in lessive soil accounted for $55.0 \%$ of $\mathrm{N}_{\min }$, and only $25 \%$ in brown soil. The share of mineral nitrogen in total nitrogen was $2.0 \%$ and $3.0 \%$ for lessive and brown soils, respectively.

\section{References}

1. ROY R.N., MISRA R. V. Soil nitrogen balance assessment and its application for sustainable agriculture and environment Sci. China C Life Sci. 48, 843, 2005.

2. SZULC P. Effect of soil supplementation with urea and magnesium on nitrogen uptake, and utilization by two different forms of maize (Zea mays L.) differing in senescence rates. Pol. J. Environ. Stud. 22, (1), 239, 2013.
3. BALÍK J., ČERNÝ J., TLUSTOŠ P., ZITKOVÁ M. Nitrogen balance and mineral nitrogen content in the soil in a long experiment with maize under different systems of $\mathrm{N}$ fertilization. Plant Soil Environ. 49, (12), 554, 2003.

4. MENG L., DING W.X., CAI Z.C. Long-term application of organic manure and nitrogen fertilizer on $\mathrm{N}_{2} \mathrm{O}$ emissions, soil quality and crop production in a sandy loam soil. Soil Biol. Biochem. 37, 2037, 2005.

5. MEYSNER T., SZAJDAK L., KU J. Impact of the farming systems on the content of biologically active substances and the forms of nitrogen in the soils. Agr. Res. 4, (2), 532, 2006.

6. STAUGAITIS G., VAISVILA Z., MAZVILA J., ARBACIAUSKAS J., ADOMAITIS T., FULLEN M.A. Role of soil mineral nitrogen for agricultural crops: Nitrogen nutrition diagnostics in Lithuania. Archiv. Agron. Soil Sci. 53, (3), 263, 2007.

7. CAMERON K.C., DI H.J., MOIR J.L. Nitrogen losses from the soil/plant system: a review. Annals Applied Biol. 162, (2), 145, 2013.

8. STOPES C., LORD E.I., PHILIPPS L., WOODWARD L. Nitrate liching from organic farms and convetional farms following best pracyice. Soil Use and management, 18, 256, 2002.

9. SOMMER S.G., SCHJOERING J.K., DENMAEAD O.T. Amonia emision from mineral fertilizers and fertilized crops. Adv. Agron., 82, 558, 2004.

10. BAKKEN L.R., BERGAUST L., LIU B., FROSTEGARD A. Regulation of denitrification at the cellular level: a clue to the understanding of $\mathrm{N}_{2} \mathrm{O}$ emission from soils. Philosophical Transactions of the Royal Society of London. Series B, Biol. Sci. 367, 1226, 2012.

11. DAMBREVILLE C., HÉNAULT C., BIZOUARD F. MORVAN T., ChAUSSOD R., GERMON J.C. Compared effects of long-term pig slurry applications and mineral fertilization on soil denitrification and its end products $\left(\mathrm{N}_{2} \mathrm{O}\right.$, $\mathrm{N}_{2}$ ). Biol. Fertl. Soils. 42, 490, 2006.

12. ELBL J., PLOSEK L., KINTL A., PRICHISTALOVA J., ZAHORA J., FRIEDEL K.F. The effect of increased doses of compost on leaching of mineral nitrogen from arable land. Pol. J. Environ. Stud. 23, (3), 1565, 2014.

13. KAUR J., SINGH J.P. Long-term effects of continuous cropping and different nutrient management practices on the distribution of organic nitrogen in soil under rice-wheat system. Plant Soil Environ. 60, (2), 63, 2014.

14. STEVENSON F.J. Nitrogen-organic forms. Methods of Soil Analysis. Part 3. Chemical Methods. Soil Sci. Soc. Amer, Amer. Soc. Agron., 1185, 1996.

15. GAO X., HAN X., ZHAN X., SUN Z., JIANG L., CHEN $H$. Effect of long-term fertilization on total nitrogen storage in a brown soil. J. Plant Nutr. Fertil. Sci., 15, (3), 567, 2009.

16. WANG J., LIN X., YIN R., CHU H., CHEN M., DAI J., QIN S. Changes in soil humic acid, microbial biomass carbon and invertase activity in response to fertilization regimes in a long-term field experiment. J. Plant Nutr. Fertil. Sci. 15, (2), 352, 2009.

17. LI Z.P., LIU M., WU X.C., HAN F.X., ZHANG T.L. Effects of long-term chemical fertilization and organic amendments on dynamics of soil organic $\mathrm{C}$ and total $\mathrm{N}$ in paddy soil derived from barren land in subtropical. China. Soil Till Res. 106, 268, 2010.

18. TOMOV T., ARTINOVA N. Effect of system mineral and organic-mineral fertilization on the humus content and humus fractions in mollic fluvisols. J. Centr. Europ. Agric. 6, (4), 2005.

19. STĘPIEŃ A., ADAMIAK J. Effect of fertilization methods in crop rotation on chemical characteristics of soil. Acta Agrophysica, 10, (2), 465, 2007. 
20. KRISTAPONYTE I. Effect of fertilization system on the balance of plant nutrients and soil agrochemical properties. Agron. Res. 3, (1), 45, 2005.

21. ZHANG J. B., ZHU T.B., CAI Z. C., QIN S. W., MÜLLER C. Effects of long-term repeated mineral and organic fertilizer applications on soil nitrogen transformations. Europ. J. Soil Sci. 63, (1), 75, 2012.

22. ERHART E., FEICHTINGER F., HARTL W. Nitrogen leaching losses under crops fertilized with biowaste compost compared with mineral fertilization. J. Plant Nutr. Fertil. Sci. 170, (5), 608, 2007.

23. RICHARDS J. E. DAIGLE J.-Y., LEBLANC P., PAULIN R., GHANEM I. Nitrogen availability and nitrate leaching from organo-mineral fertilizers. Can. J. Soil Sci. 73, (2), 197, 1993.
24. HABERLE J., KÁŠ M. Simulation of nitrogen leaching and nitrate concentration in a long-term field experiment. J. Centr. Europ. Agric. 13, (3), 416, 2012.

25. PIOTROWSKA A. Spatial variability of total and mineral nitrogen content and activites of the N-cycle Enzymes in the Luvisol Topsoil. Pol. J. Environ. Stud. 20, (6), 1565, 2011.

26. ANGGRIA L., KASNO A., ROCHAYATI S. Effect of organic matter on nitrogen mineralization in flooded and dry soil ARPN. J. Agric. Biol. Sci. 7, (8), 586, 2012.

27. DRESLER S., BEDNAREK W., TKACZYK P. Nitrate nitrogen in the soils of eastern Poland as influenced by type of crop, nitrogen fertilisation and various organic fertilizers. J. Centr. Europ. Agric. 12, (2), 367, 2011. 